\title{
Shizuo Hattori (1902-), His Scientific Life and Work
}

In recognition of his devotional contribution to the Botanical Society of Japan during his presidency in the past ten years (1955-1965), the Society decided to honour at the general meeting of the 30th Congress held at Tokyo in October, 1965, Dr. Shizuo Hattori, Professor Emeritus of the University of Tokyo, by the Commemoration issue of the Botanical Magazine. Not only all members of the Society but also his friends and colleagues in and out of the country offer their sincere gratitude to Professor Hattori, longing for his everlasting and fruitful contributions to the Society and also to the botanical science in Japan.

Sh. Hattori was born at Tokyo February 22, 1902, and educated at the First Higher School and then at the Tokyo Imperial University (called the University of Tokyo since 1947). Early in his younger higher school age (1919-1920), he received a strong influence from one of his aunts, a physician who devoted herself to the relief of lepers, and his interest was beset with a problem on the then undeveloped chemotherapy of leprosy, by which his eyes were perhaps first opened to the science of living things. During succeeding three years, he spent his student life in the Tokyo Imperial University, where he gained a fundamental knowledge on the science of botany. In the meantime, his chief concern was directed to a biochemical approach to the physiology of plants, and he studied under the personal guidance of Professor Keita Shibata, a most prominent pioneer in plant biochemistry, a science, which arose at that time from mere plant physiolosy. In those days, Hattori was particularly inspired by the brilliant works of Richard Willstätter with Arthur Stoll through their well-known publications 'Untersuchungen über Chlorophyll' and 'Untersuchungen über die Assimilation der Kohlensäure'. Of course, a number of foreign books of physical and chemical sciences laid a sound basis for wider scope of his scientific attainment in later years. Just it was toward this time that he got in marriage with Miss Fumiko Fujie who was brought up in the old city of Kyoto and bestowed with refined culture.

Hattori began his scientific career with an investigation of flavone compounds widely occurring in higher plants. This was an extention of a chemical branch of botany, which had been explored by his teacher Shibata shortly before that time. In the last year of his studentship in the Tokyo Imperial University, a maiden work in this line of research was published in Acta Phytochimica (1924-1925) entitled 'Untersuchungen über das Acacciin, ein neues Flavonglykosid aus den Blättern von Robinia pseudacacia L.' Being confronted by rather tedious and time-consuming processes of chemical analyses, his attention was directed to a comprehensive study of spectrographic qualification of flavone compounds in general. For this purpose, a variety of compounds natural and synthetic were prepared by himself, and examined spectrographically one after another. This elaborate work came to a completion in 1932, as can be seen in a series of papers 'Beiträge zur Spektrographie der Flavone, I-V'. This was his doctorate work. During this period, analytical studies were also carried out on a number of plant constituents belonging to the classes of flavones, flavanones, and coumarines. In the following decade, Hattori's work in the same field was much extended in conjunction with the activities of his younger students including the 
present writers.

To a great misfortune for himself and also for all in the laboratory, his wonderful activity was interrupted by a sudden and serious attack of tuberculosis in the midsummer of 1932. However, in behalf of unusual perseverance and defence against disease not only of himself but also of his wife, after three years' recuperation, he was able to regain his complete health and to resume his laboratory work.

Here, it should be remembered that a comprehensive review of plant pigments was accomplished by him during that recuperation period and published as a voluminous handbook of 'Plant Pigments' for the benefit of fellow researchers working in the same field.

After retirement of his teacher, Prof. Shibata, he obtained in 1938 the position of assistant professor in the Tokyo Imperial University, taking charge of the lecture of plant biochemistry.

In later years, Hattori also took up the studies of plant sugars and on the deathring occurring on leaves (in sensu of Hans Molisch). Moreover, enzymic degradation of flavonoids became his major concern in a whole series of his consecutive investigations on this group of compounds, as listed below.

In 1944, he took the position of the professor of the Tokyo Imperial University, and devoted himself to the education and training of younger students as well as research workers coming to his laboratory. From that time on, a greater part of his implicit talent was displayed in the administration of university duties. Apart from his explicit knowledge in botanical science, he had a deep interest in the study of Japanese language, and this is seemingly an intangible cultural property that had been left by his father who had a profound knowledge on Japanese classical literature. This had driven him to take a membership in the governmental council of Japanese language for about six years since 1950 .

In 1962, he reached the age-limit and retired from the University of Tokyo, where he had been educated and later had worked out many investigations, through which a number of promising research workers were well trained and they have been actively working and playing an important role in their respective field.

On account of outstanding ability in science itself and its administration, he was nominated in 1962 to the President of the Okayama University, and devoted himself to an improvement and modernization of University activities there, but sorry to say, he retired from this university because of afterbrain thrombosis with which he was so unfortunately attacked on July 12, 1963.

As mentioned above, Professor Hattori's characteristic in a later half of his career was that the final goal of his scientific achievement lies in an improvement of education and the promotion of research in the science of Japan. In this connection it was particularly appreciated by the majority of chemists and biochemists to have established the Department of Biophysics and Biochemistry in the Faculty of Science of the University of Tokyo, only one department of biochemistry or biophysics in Japan then erected in pure scientific field, in the period of his Deanery from 1955 to 1957.

The writers now conclude the writing informing you that many articles have been contributed by his former students and friends among whom some of his foreign friends he knew since years contributed to this issue of Hattori Commemoration Number of the Botanical Magazine. 


\section{Selected Bibliography}

1924-5 Untersuchungen über das Acaciin, ein neues Flavonglykosid aus den Blättern von Robinia pseudacacia L. Acta Phytochim. 2: 99.

1928-9 Beiträge zur Spektrographie der Verbindungen aus der Flavonreihe. I. Spektrographische Untersuchung über einige Derivate des Flavons, Flavonols und Styrylchromonols. Ibid. 4: 41.

Beiträge zur Spektrographie der Verbindungen aus der Flavonreihe. II. Synthese zwei neuer Flavonglykoside. Spektrographische Einflüsse der Zuckerbindung und der Acylierung. Ibid. 4:63.

Über Isosakuranetin aus den Blüten von Pseudaegle trifoliata. Ibid. 4: 219. Über Corylopsin, einen kristallinischen Bestandteil aus der Rinde von Cory. lopsis spicata. Ibid. 4: 327.

1930 ダフニンの構造. J. pharm. Soc. Japan 50: 539.

1930-1 Beiträge zur Spektrographie der Flavonreihe. III. Über die Konstitution des Wogonins. Acta Phytochim. 5: 99.

Weitere Untersuchungen über die Konstitution des Wogonins. Beiträge zur Spektrographie der Flavone. IV. Ibid. 5: 219.

1932 Beiträge zur Spektrographie der Flavone. V. Über die Beziehungen zwischen Lichtabsorption und Hydroxylsubstitution bei den Flavonderivaten. Ibid. 6: 131 .

1937 Studien über Anthocyane. II. Über die Farbstoffe aus den roten Herbstblättern von einigen Acer-Arten. Ibid. 10: 129.

Über das Quercetinglucosid aus Trifolium-Blüten. Ibid. 10: 147.

1940 Lespedin, ein Birhamnosid des Kämpferols. Proc. Imp. Acad. Japan 16: 9.

1942 Über die Struktur des Glykosids Trifolins aus den Blüten von Trifolium pratense, nebst einer Bemerkung über einen gelben Begleitstoff. Acta Phytochim. 13: 99.

1944 Untersuchungen über Flavanon-glykoside. I. Über Poncirin, das Glykosid aus den Blüten von Poncirus trifoliata. Ibid. 14: 1.

1948 タラヨウの葉の黑変について. Bot. Mag. Tokyo 61: 70.

1949 Über ein Luteolinglykosid in den Blättern von Humulus japonicus Sieb. et Zucc. Acta Phytochim. 15: 233.

1950 On a flavone glycoside of the leaves of Pueraria thunbergiana. Misc. Rep. Res. Inst. Natur. Resourc. 17-18: 52.

Studies on death-ring. I. On an enzyme hydrolyzing aucubin in the leaves of Aucuba japonica. Ibid. 17-18: 163.

1951 The sugars in the seeds and seedlings of Pinus thunbergii. Arch. Biochem. Biophys. 34: 121.

1952 Rhoifolin, a new flavone glycoside, isolated from the leaves of Rhus succedanea. Ibid. $37: 85$.

1953 Anthochlor pigments of Cosmos sulphureus, Coreopsis lanceolata and C. saxicola. J. Amer. chem. Soc. $75: 1900$.

On a probable enzymatic conversion of hydroxychalcone glycoside into hydroxybenzalcoumaranone glycoside. Ibid. 75: 2277.

1954 Occurrence of shikimic acid in the leaves of gymnosperms. Physiol. Plantarum $7: 283$.

1955 On the formation of carthamin in the flowers of Carthamus tinctorius. Arch. 
Biochem. Biophys. 54: 93.

Über den aus Stammblasen von Pinus thunbergii ausgeschiedenen Honig. $Z$. f. Bot. $43: 125$.

Studies on the browning and blackening of plant tissues. II. On the interaction of dopa and a specific oxidase in the leaves of Stizolobium hassjoo. Physiol. Plantarum 8: 63.

Studies on the browning and blackening of plant tissues. III. Occurrence in the leaves of Dahlia and several other plants of chlorogenic acid as the principal browning agent. Ibid. 8: 358.

Studies on the browning and blackening of plant tissues. IV. Chlorogenic acid in the leaves of Nicotiana tabacum. Ibid. 8: 594.

1956 Seasonal changes in flavone and flavanone glycosides in the fruits and flowers of Poncirus trifoliata. Sci. Proc. Royal Dublin Soc. 27: 139.

Glucosides flavoniques des feuilles de Calystegia japonica et $C$. hederacea. Bull. Soc. chim. biol. 38 : 557.

1958 The degradation of rutin by an imperfect fungus of the genus Pullularia. Bot. Mag. Tokyo 71: 43.

Biological conversion of shikimic acid. Arch. Biochem. Biophys. 74: 480.

Über das Verhalten der Stärke in den Chloroplasten. Z. f. Bot. 46: 355.

Oligosaccharides in Verbascum thapsus L. Bot. Mag. Tokyo 71: 417.

1959 Crystallization and properties of commelinin, a blue metallo-anthocyanin from Commelina. Ibid. $72: 325$.

Stizolobic acid: a new amino-acid in Stizolobium hassjoo. Nature 183: 1116. A new phenolic glycoside in Viburnum furcatum Blume. J. Amer. chem. Soc. $81: 4424$.

1961 Prodigiosin-Kohlehydrat-Eiweiss-Komplex, ein extracelluläres Chromoproteid von Serratia marcescens. Naturwiss. 48: 305.

1966 The changes in the starch content of tobacco leaves by dark treatment. Bot. Mag. Tokyo 79: 376 .

\section{Kôzô HAYASHI* and Masami SHIMOKORIYAMA**}

* Botanical Department, Faculty of Science, Tokyo Kyoiku University, Tokyo, Japan.

** Department of Botany, Faculty of Science, University of Tokyo, Tokyo, Japan. 